\title{
ANALISIS YURIDIS PEMBATALAN HAK ATAS SERTIFIKAT TANAH OLEH PENGADILAN TATA USAHA NEGARA AKIBAT SENGKETA KEPEMILIKAN GANDA \\ (STUDI ANALISA PUTUSAN NOMOR 103/G/2016/PTUN-BDG)
}

\author{
Muhammad Reza Syariffudin Zaki $\triangle 1$, Reza Mahendra $\triangle^{2}$ \\ ${ }^{1}$ Binus University, Jakarta, Indonesia \\ ${ }^{2}$ STIH IBLAM, Jakarta, Indonesia

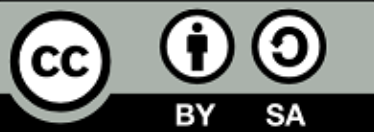

DOI: http://dx.doi.org/10.33603/hermeneutika.v3i2

Diterima: 14 Mei 2020; Direvisi: 20 Juli 2020; Dipublikasikan: Agustus 2020

\begin{abstract}
Abstrak: Kegiatan pendaftaran tanah bertujuan untuk menjamin kepastian hukum dan perlindungan hukum kepada pemegang hak atas tanah. Peraturan mengenai pendaftaran tanah di Indonesia mengacu kepada Undang Undang Nomor 5 Tahun 1960 Tentang Peraturan Dasar pokok-pokok Agraria yang diatur lebih lanjut dalam Peraturan Pemerintah Nomor 24 tahun 1997. Di Indonesia masih banyak masalah dalam bidang pertanahan, salah satunya adalah kepemilikan ganda atas tanah. Sengketa tanah dapat diselesaikan dengan berbagai cara seperti musyawarah, penyelesaian melalui badan peradilan, atau arbritase. Penelitian ini menganalisa mengenai permasalahan kepemilikan ganda atas tanah serta upaya untuk menghindari terjadinya masalah kepemilikan ganda dengan mempelajari kasus sengketa tanah Hj Sutiah alias Hajjah Sutiah dkk. dengan kantor Bandung dan putusan pengadilan Tata Usaha Negara Nomor 103/G/2016/PTUN-BDG. Cara menyelesaikan sengketa tanah sangatlah umum untuk diketahui dan dilaksanakan, namun bagaimana cara untuk mengatasi agar permasalahan yang sama tidak terjadi lagi. Keputusan Tata Usaha Negara menurut ketentuan Pasal 1 angka 3 UU 5/1986 adalah suatu penetapan tertulis yang dikeluarkan oleh Badan atau Pejabat Tata Usaha Negara yang berisi tindakan hukum Tata Usaha Negara berdasarkan peraturan perundang-undangan yang berlaku, yang bersifat konkret, individual, dan final, yang menimbulkan akibat hukum bagi seseorang atau badan hukum perdata. Berkaitan dengan sertifikat tanah, sertifikat tanah dikeluarkan oleh pemerintah, dalam hal ini Badan Pertanahan Nasional selaku Badan Tata Usaha Negara ditujukan kepada seseorang atau badan hukum (konkret, individual) yang menimbulkan akibat hukum pemilikan atas sebidang tanah yang tidak memerlukan persetujuan lebih lanjut dari instansi atasan atau instansi lain (final).
\end{abstract}

Kata Kunci : Pendaftaran Tanah, Sertifikat Ganda, Sengketa Tata Usaha Negara

\footnotetext{
${ }^{1}$ Muhammad Reza Syariffudin Zaki

Email: rezazaki@gmail.com

${ }^{2}$ Reza Gunawan

Email: rezagunawan@gmail.com
} 


\section{PENDAHULUAN}

Tanah merupakan salah satu modal utama dalam mewujudkan cita-cita nasional yang hendak dicapai dengan menyelenggarakan pembangunan. Dalam kegiatan pembangunan diperlukan tanah, baik untuk diusahakan atau diolah untuk usaha pertanian, perkebunan, peternakan, perikanan ataupun sebagai tempat permukiman dan sebagai kantor-kantor untuk berbagai kegiatan pelaksanaan tugas Negara di bidang pemerintahan, pertahanan dan keamanan. Selain itu juga sebagai pusat kegiatan produksi, perdagangan, transportasi / komunikasi, pendidikan, peribadatan dan rekreasi.

Sebagai wadah atau sarana, tanah adalah benda yang mempunyai sifat unik, dikatakan demikian karena di satu sisi tanah adalah sumber daya non hayati, artinya bahwa tanah adalah suatu benda yang tidak dapat memperbaharui dirinya menjadi banyak. Di lain pihak tanah sangat dibutuhkan oleh setiap manusia. Hampir tidak ada kegiatan manusia yang tidak berkaitan dengan tanah. Manusia memerlukan rumah untuk tempat tinggal, sebagai sarana perhubungan darat, sebagai tempat untuk berusaha, sebagai tempat untuk berekreasi dan sebagai tempat untuk peribadatan, pendidikan dan sebagainya. Dengan kata lain bahwa dalam perkembangannya, kebutuhan manusia akan tanah ini dapat dikelompokan menjadi kebutuhan yang bersifat pribadi, untuk kegiatan usaha, untuk kegiatan-kegiatan khusus, dan untuk kepentingan umum.

Salah satu fungsi penting dalam bidang pertanahan adalah bagaimana menjamin adanya kepastian hukum mengenai berbagai hak atas tanah dan perlindungan terhadap pemegang hak. Oleh karena itu dalam Pasal 19 Undang-undang Nomor 5 Tahun 1960 tentang Peraturan Dasar Pokok-pokok Agraria, yang lazim disebut Undang-undang Pokok Agraria disingkat UUPA, diatur bahwa, untuk menjamin kepastian hukum atas tanah perlu diselenggarakan Pendaftaran Tanah diseluruh wilayah Indonesia.

Dalam pembangunan, peranan tanah untuk pemenuhan berbagai keperluan akan meningkat baik sebagai tempat bermukim maupun untuk kegiatan usaha. ${ }^{3}$ Sehubungan dengan itu akan meningkat pula kebutuhan mengenai jaminan kepastian hukum di bidang pertanahan. Pendaftaran tanah, sebagai pelaksanaan Pasal 19 UndangUndang Nomor 5 Tahun 1960 merupakan salah satu upaya pemerintah untuk memberikan jaminan kepastian hokum.

Jaminan kepastian hukum tersebut meliputi : jaminan kepastian hukum mengenai orang atau badan hukum yang menjadi pemegang hak (subyek hak atas tanah); jaminan kepastian hukum mengenai letak, batas, dan luas suatu bidang tanah (obyek hak atas tanah); dan jaminan kepastian hukum mengenai hak-hak atas tanahnya ${ }^{4}$.

Jaminan kepastian hukum mengenai obyek hak atas tanah sangat erat kaitannya dengan kegiatan pengukuran dan pemetaan tanah yang menghasilkan data fisik. Data fisik yang dihasilkan dari pengukuran bidang-bidang tanah tersebut kemudian dipetakan ke dalam Peta Dasar Pendaftaran ataupun Peta Pendaftaran. Oleh karena itu, peta-peta yang dihasilkan harus dapat memberikan gambaran yang jelas mengenai letak bidang-bidang tanah yang tergambar didalamnya terhadap bidangbidang tanah yang ada dalam satu wilayah.

Selama ini, masalah pertanahan khususnya yang terkait dengan kegiatan pengukuran dan pemetaan tanah sangat mudah terjadi. Salah satu penyebab permasalahan tersebut adalah banyaknya peta yang digunakan oleh suatu kantor pertanahan untuk memetakan bidang-bidang

\footnotetext{
3 Yulia Mirwati, 2000, Konflik-konflik Mengenai Tanah Ulayat Dalam Era Reformasi di Daerah Sumatra Barat, Disertasi, Universitas Sumatera Utara, Medan

4 A. P. Parlindungan, 1993, Komentar UndangUndang Pokok Agraria, Bandung: Mandar Maju, hal 27
} 
tanah yang terdaftar sehingga kepastian letak suatu persil atau bidang tanah menjadi tidak terjamin. Permasalahan tersebut dapat diatasi apabila ada kepastian data mengenai bidang-bidang tanah yang terdaftar pada kantor pertanahan. Untuk menciptakan kepastian mengenai bidang-bidang tanah yang terdaftar tersebut harus dibangun satu sistem peta pendaftaran secara tunggal. Dengan peta tunggal, setiap bidang tanah yang terdaftar hanya akan dipetakan pada satu peta untuk satu wilayah dalam lokasi yang bersangkutan.

Eko Budi Wahyono mengemukakan bahwa 'sudah saatnya dalam satu kantor pertanahan mempunyai Peta Pendaftaran dalam satu sistem dan semua kegiatan pengukuran dan pemetaannya mengacu pada satu peta (Peta Pendaftaran Sistem Tunggal) tersebut ${ }^{5}$.

Berikut, dalam rangka melaksanakan ketentuan Undang-Undang (UU) Nomor 5 Tahun 1960 tentang Ketentuan PokokPokok Agraria atau yang lebih kita kenal dengan singkatan UUPA, Peraturan Pemerintah Nomor 10 Tahun 1961 direvisi dengan Peraturan Pemerintah (PP) Nomor 24 Tahun 1997 yang dalam masyarakat lebih dikenal dengan singkatan PP 24/1997 yang mempunyai kedudukan sangat strategis dan menentukan, bukan hanya sekedar sebagai pelaksana ketentuan Pasal 19 Undang-Undang Pokok Agraria (UUPA), tetapi lebih dari itu ia menjadi tulang punggung yang mendukung berjalannya administrasi pertanahan dan hukum pertanahan ${ }^{6}$.

Namun, semenjak ditetapkan pada tanggal 25 Maret 1961 Peraturan Pemerintah Nomor 10 Tahun 1961 dan

\footnotetext{
${ }^{5}$ Eko Budi Wahyono, Alternatif Pemanfaatan Citra Satelit IKONOS Untuk Peta Pendaftaran Sistem Tunggal, Makalah Untuk Forum Ilmiah Tahunan Ikatan Surveyor Indonesia, (tidak dipublikasikan), Yogyakarta, 2005, hal 98

6 Abdurrahman, Kedudukan Hukum Adat dalam Perundang-Undangan Agraria, Jakarta: Akademika Presindo, 2003, hal 53
}

direvisi dengan Peraturan Pemerintah Nomor 24 Tahun 1997 tentang Pendaftaran Tanah hingga saat ini masih belum berjalan efektif untuk seluruh wilayah Indonesia. Penetapan berlakunya yang dibuat secara bertahap untuk berbagai daerah di Indonesia kelihatannya lebih banyak bersifat formal, sedangkan dalam realita ternyata tidak semulus yang dibayangkan orang, masih terdapat banyak persoalan problematik kepastian hukum kepemilikan atas tanah yang telah bersertifikat hak milik.

Apakah problematik tersebut memang disebabkan oleh substansi peraturan yang banyak tidak sesuai lagi dengan kondisi dan situasi masa kini, ataukah termasuk administrasi pertanahannya. Hal ini penting untuk diperhatikan, karena bagaimanapun baiknya ketentuan penyempurnaan dibuat, akan tetapi belum ada dukungan positif, katakanlah dalam sistem administrasi pertanahan misalnya, peraturan ini juga akan mengalami nasib yang sama dengan Peraturan Pemerintah (PP) Nomor 24 Tahun 1997 tentang Pendaftaran Tanah yang ingin direvisi sekarang.

Seiring dengan umurnya yang menginjak ke-13 tahun, secara detail isi dari Peraturan Pemerintah (PP) Nomor 24 Tahun 1997 tentang Pendaftaran Tanah memang banyak yang sudah tidak sesuai lagi, akan tetapi secara prinsip sebenarnya masih ada hal yang perlu dipertahankan mengingat banyak berkaitan dengan sendi dasar hukum pertanahan yang digariskan dalam UndangUndang Pokok Agraria (UUPA). Selain dari pada itu, apapun perubahan yang dilakukan diharapkan tidak akan mempersulit warga masyarakat yang ingin mendapatkan kepastian hukum dan kepastian hak atas tanahnya ${ }^{7}$.

Pengertian sertifikat menurut Peraturan Pemerintah Nomor 10 Tahun 1961 pada Pasal 13 Ayat 3 (dalam Soetmo

\footnotetext{
${ }^{7}$ Imam sudiyat, Hukum Adat Sketsa Asas, Cet ke IV, Yogyakarta: Liberty, 2018, hal 40
} 
2007:90) dijelaskan bahwa "salinan bukutanah dan surat ukur setelah di jahit menjadi satu bersama-sama dengan satu kertas sampul yang bentuknya ditetapkan oleh menteri Agraria, disebut sertifikat dan diberikan kepada yang berhak". Pengertian diatas merupakan surat tanda bukti hak atas tanah milik. Selanjutnya surat tanda bukti hak dalam Undang-undang Pokok Agraria bagian II menyangkut Pendaftaran Tanah Pasal 19 Ayat 2 (dalam Ranoemihardja 2007:236) dijelaskan bahwa "pendaftaran tersebut dalam Ayat 1 Pasal ini meliputi: (a). pengukuran, perpetaan dan pembukaan tanah; (b). pendaftaran hak-hak atas tanah dan peralihan hak-hak tersebut; (c). pemberian surat-surat tanda-bukti- hak, yang berlaku sebagai alat pembuktian yang kuat". Menurut Peraturan Pemerintah Nomor 24 Tahun 1997, sertifikat adalah adalah surat tanda bukti hak sebagaimana dimaksud dalam Pasal 19 Ayat (2) huruf c UUPA untuk hak atas tanah, hak pengelolaan, tanah wakaf, hak milik atas satuan rumah susun dan hak tanggungan yang masing-masing sudah dibukukan dalam buku tanah yang bersangkutan. Kalau dilihat Pasal 19 Ayat (2) huruf c UUPA, maka sertifikat itu merupakan surat tanda bukti hak yang berlaku sebagai alat bukti yang kuat. Selanjutnya Pasal 32 Ayat (1) Peraturan Pemerintah Nomor 24 Tahun 1997, sertifikat merupakan surat tanda bukti hak yang berlaku sebagai alat pembuktian yang kuat mengenai data fisik dan data yuridis yang termuat di dalamnya, sepanjang data fisik dan data yuridis tersebut sesuai dengan data yang ada dalam surat ukur dan buku tanah yang bersangkutan. Selain pengertian sertifikat yang diberikan oleh undang-undang secara otentik, ada juga pengertian sertifikat yang diberikan oleh para sarjana. Salah satunya adalah K. Wantjik Saleh yang menyatakan bahwa sertifikat adalah salinan buku tanah dan surat ukurnya setelah dijilid menjadi satu bersama-sama dengan suatu kertas sampul yang bentuknya ditetapkan oleh Menteri.
Dari uraian diatas dapat disimpulkan bahwa sertifikat adalah pendaftaran tanah hak milik untuk ditindaklanjuti dalam rangkaian kegiatan yang dilakukan oleh pemerintah secara terusmenerus, berkesinambungan dan teratur, meliputi pengumpulan, pengolahan, pembukuan dan penyajian serta pemeliharaan data fisik dan data yuridis dalam bentuk peta dan daftar, mengenai bidang-bidang tanah dan satuan rumah susun, termasuk pemberian surat tanda bukti haknya bagi bidang-bidang tanah yang sudah ada haknya dan hak milik atas satuan rumah susun serta hakhak tertentu yang membebaninya

Data dari BPN menyebutkan pada tahun 2016 terdapat 2.865 kasus sengketa tanah skala besar yang belum terselesaikan. ${ }^{8}$ Ketua Mahkamah Agung Republik Indonesia, dalam suatu kesempatan menyebutkan bahwa separuh lebih kasus yang masuk ke Mahkamah Agung adalah perkara tanah. Akar permasalahannya, sebagian besar karena kacaunya administrasi pertanahan. ${ }^{9}$

Hal hal seperti yang disebutkan di atas menunjukkan belum adanya jaminan kepastian hukum bagi kepemilikan atas tanah. Hukum melalui peraturan perundangundangan yang ada belum mampu mewujudkan kepastian hukum ini, hal ini terjadi karena adanya kendala dalam pelaksanaan hukum itu. Mengenai penyelesaian sengketa pertanahan, ada 3 (tiga) cara untuk mengatasinya, yaitu:

1. Melalui penyelesaian secara langsung oleh Para Pihak dengan musyawarah;

2. Melalui badan peradilan baik itu ke pengadilan umum secara perdata atau pidana atau ke peradilan tata usaha negara.

3. Arbitrase dan alternatif penyelesaian sengketa. ${ }^{10}$

\footnotetext{
8 Khairina, "Kalau bisa Dipersulit, Kenapa Dipermudah?" Kompas (30 Juni 2017): hal 37

${ }^{9}$ Ibid.

10 Arie S. Hutagalung (B), Tebaran Pemikiran Seputar Masalah Hukum Tanah), (Jakarta:
} 
Cara penyelesaian seperti ini memang telah dilaksanakan, namun sebaiknya diupayakan usaha untuk mencegah permasalahan dari pada membiarkan masalah yang sama muncul lagi baru kemudian diadakan penyelesaian sengketanya. Permasalahan yang ingin penulis angkat adalah permasalahan yang sering terjadi, yaitu sertifikat hak kepemilikan atas tanah. Bagaimana mungkin satu satu sertifikat hak atas tanah dimiliki oleh dua orang yang berlainan. Hal ini jelas merupakan penyimpangan. Permasalahan ini harus dilihat mulai dari proses awal permohonan sertifikat hak atas tanah itu sendiri, karena kekacauan administrasi tanah sudah dimulai dari proses ini, seperti misalnya untuk membuat surat rekomendasi hak atas tanah negara yang bisa didapat di lingkungan kelurahan atau kecamatan, kerap kali masyarakat harus membayarkan sejumlah uang. ${ }^{11}$

Seluruh tahapan mempengaruhi terbitnya suatu sertipikat, maka bila terjadi kesalahan haruslah dilihat tahapan manakah yang tidak benar itu. Untuk upaya penyelesaian sengketa, kepemilikan ganda atas tanah pun harus diupayakan seluruh tahapan berjalan dengan benar dan segala penyimpangan harus dapat dihentikan.

Ketidakcermatan dan ketidaktelitian

BPN dalam menerbitkan Sertifikat sebagaimana yang dipersoalkan Penggugat Seyogianya diperlukan pemeriksaan lanjutan dengan meneliti data - data fisik dan data yuridis baik secara langsung dilapangan maupun dalam hal penyelidikan riwayat tanah dan penilaian kebenaran alat bukti pemilikan atau penguasaan tanah sehingga dapat diperoleh kebenaran materil siapa pemiilk yang sebenarnya. Kemudian melakukan penerbitan Sertifikat Hak Milik terhadap tanah-tanah yang sudah ada surat

Lembaga Pemberdayaan Hukum Indonesia, 2015), 372 .

${ }^{11}$ Khairina, Loc.cit ukurnya. Sedangkan faktor penyebab terbitnya Sertifikat diatas tanah yang dikuasai pihak lain yaitu faktor ekstern dan intern. Faktor Ekstern diantaranya terjadi karena tidak dilaksanakannya Undang undang Pokok agraria dan peraturan pelaksanaannya secara konsekuen dan bertanggung jawab disamping masih adanya orang yang berbuat untuk memperoleh keuntungan pribadi. Sedangkan faktor Ekstern karena ketidakcermatan Tergugat dalam memeriksan data yuridis. Sedangkan didalam kesalahan prosedur dalam Penerbitan Sertifikat Hak Milik akan mengakibatkan Sertifikat menjadi cacat hukum administatif sehingga tidak berlaku sebagai alat bukti yang kuat.

\section{METODE PENELITIAN}

Metode penelitian dalam penyusunan penulisan skripsi ini, menggunakan metode yuridis normatif yaitu penelitian dengan menggunakan data sekunder. Adapun menyangkut tentang teknik pengumpulan data serta bahan penelitian adalah sebagai berikut:

1. Teknik Pengumpulan Data

Studi kepustakaan (Library research), dilaksanakan dengan cara mempelajari berbagai literatur yang berhubungan dengan obyek penelitian.

2. Bahan Penelitian

Data sekunder yang digunakan dalam penelitian hukum ini mencakup:

a. Bahan hukum primer, yang mencakup peraturan perundangundangan yang berlaku, yakni antara lain :

1) Undang-Undang Dasar 1945

2) Undang-undang Nomor 5

Tahun 1960 tentang

Peraturan Dasar Pokok-

pokok Agraria beserta

Peraturan Pelaksanaannya.

3) Peraturan Pemerintah Nomor 24 Tahun 2007 Tentang Pendaftaran Tanah. 
4) Putusan 103/G/2016/PTUN-BDG

b. Bahan hukum sekunder, yaitu terdiri dari hasil-hasil penelitian yang telah ada sebelumnya berkenaan dengan permasalahan penelitian dan kepustakaankepustakaan (termasuk bahan dari hasil seminar) yang berkaitan dengan objek penelitian.

c. Bahan hukum tersier, yaitu bahan yang memberikan petunjuk maupun penjelasan terhadap bahan hukum primer dan bahan hukum sekunder. Yang terdiri dari kamus hukum, ensiklopedi dan kamus lainnya.

3. Metode Analisa Data : bersifat kualitatif dan Komparatif

Data yang sudah terkumpul diseleksi, diklasifikasikan dan disusun dalam suatu tabulasi sesuai dengan kelompok pembahasan yang telah direncanakan. Selanjutnya dilakukan pembahasan (analisis), dengan cara membandingkan data terhadap teori-teori, maupun ketentuan-ketentuan yang terdapat dalam peraturan perundangundangan khususnya yang menyangkut dengan objek penelitian dengan mengacu pada pola pikir induktif dan deduktif. Dalam Kamus besar bahasa Indonesia pola pikir induktif adalah pola pikir yang berpijak pada fakta-fakta yang bersifat khusus kemudian diteliti dan akhirnya ditemukan pemecahan persoalan yang bersifat umum. Pola pikir deduktif adalah pola berfikir dengan menggunakan analisa yang berpijak dari pengertian-pengertian atau fakta-fakta yang bersifat umum, kemudian diteliti dan hasilnya dapat memecahkan masalah khusus.

4. Metode Penyajian Data

Setelah semua data diperoleh yang merupakan hasil dari studi kepustakaan dan komparasi, kemudian data-data tersebut diteliti kembali melalui proses editing. Hal ini diperlukan untuk memeriksa dan meneliti data yang diperoleh, untuk menjamin agar dapat dipertanggungjawabkan. Setelah itu diolah menjadi suatu laporan penelitian, mulai dari permasalahan sampai hasil kesimpulan akhir kemudian disajikan dalam bentuk skripsi, yang berupa uraian tertulis yang tersusun rapi dan sistematik.

\section{ANALISIS}

Pendaftaran tanah perlu dilakukan untuk memberikan kepastian hukum terhadap orang yang menguasai dan memiliki tanah agar nantinya mempunyai kekuatan hak didepan hukum dan Negara. Jadi misalnya seseorang memiliki tanah tapi belum ada sertifikatnya otomatis belum bisa diakui dan hanya bisa mengatakan bahwa tanah tersebut adalah tanahnya dan mungkin saja orang lain ikut mengakuinya juga, karna itulah pentingnya pendaftaran tanah dan penerbitan sertifikat di atas tanah yang dimiliki agar seseorang mempunyai dasar kepemilikan hak atas tanah. Sertifikat sebagai surat tanda bukti hak atas tanah seseorang yang didalamnya memuat data fisik dan data yuridis yang telah didaftar dalam buku tanah, merupakan pegangan kepada pemiliknya akan bukti-bukti haknya yang tertulis.

Oleh karenanya dalam penerbitan sertifikat hak atas tanah, setiap satu sertifikat hak atas tanah diterbitkan untuk satu bidang tanah. Namun nyatanya sampai saat ini masih sering terjadi kasus tentang sertifikat ganda dimana satu bidang tanah mempunyai lebih dari satu sertifikat.

Muhammad Iqbal SH Hakim Pengadilan Tata Usaha Negara berpendapat "Pertama; seperti ini, yang banyak terjadi orang menyatakan sudah ada sertifikatnya kemudian dia tidak manfaatkan tanah tersebut, seperti tanah kosong yang tidak dikelola, tidak dimanfaatkan sampai 
muncul semak-semak, belukar dan sebagainya. Kemudian ada orang datang memanfaatkan tanah tersebut selanjutnya dia daftarkan juga, dia tidak tau kalau diatas tanah tersebut sudah ada pemiliknya, oleh Badan Pertanahan Nasional dia pergi survei, diukur makanya terbitlah sertifikat. Kedua; persoalan dari pihak pertanahan itu sendiri, artinya data-data yang ada di pertanahan itu belum mampu secara jelas menentukan bahwa diatas tanah tersebut sudah ada sertifikat dan juga Badan Pertanahan Nasional yang belum secara lengkap mengimpentarisir tanah-tanah mana yang sudah terdaftar. Yang Ketiga; Faktor dari pemerintahan setempat, kelurahan atau desa yang tidak mempunyai data mengenai tanah-tanah yang sudah disertifikatkan atau sudah ada penguasaannya".

Dalam Sertifikat Ganda yang perlu di perhatikan adalah kasusnya, karena bisa disebabkan berbagai hal, kebanyakan yang menyebabkan munculnya Sertifikat Ganda adalah : Kesalahan dari pemilik tanah itu sendiri yang tidak memperhatikan tanah miliknya dan tidak memanfaatkanya dengan baik sehingga di ambil alih oleh orang lain dan kemudian di manfaatkan karna merasa bahwa tanah tersebut tidak bertuan atau tidak ada pemiliknya. Karna merasa sudah lama menguasai tanah itu, orang tersebut kemudian mengklaim bahwa tanah tersebut adalah miliknya dan menerbitkan sertifikat di atas tanah tersebut tanpa mengetahui bahwa diatas tanah itu sudah ada sertifikatnya, atau Sewaktu dilakukan pengukuran atau penelitian dilapangan, pemohon dengan sengaja atau tidak sengaja menunjukkan letak tanah dan batas tanah yang salah, serta Adanya kesengajaan dari pemilik tanah untuk mendaftarkan kembali sertifikat yang sebenarnya sudah ada dengan memanfaatkan kelemahan lembaga Badan Pertanahan Nasional karena merasa pembuatan sertifikat baru lebih mudah dan lebih murah daripada melakukan peralihan hak atas tanah. Selanjutnya dari Badan pertanahan Nasional karena tidak adanya basis data mengenai bidang-bidang tanah baik yang sudah terdaftar maupun yang belum terdaftar. Seharusnya tanah-tanah yang didaftarkan pada Kantor Pertanahan dilakukan pencatatan dan pencoretan pada petapeta pendaftaran, sehingga apabila tanah tersebut didaftarkan lagi maka dapat diketahui tanah tersebut sudah bersertifikat atau belum. Jadi, data yang ada belum sistematis meskipun sekarang sudah ada perbaikan tapi masih banyak sertifikatsertifikat lama tidak terimpentarisir sehingga memungkinkan munculnya sertifikat ganda karna disini badan pertanahankan tinggal terima permohonan. Atau karena ketidak telitian Pejabat Kantor Pertanahan dalam menerbitkan sertifikat tanah, disamping masih adanya orang yang berbuat untuk memperoleh keuntungan pribadi sehingga bertindak menyeleweng dalam artian tidak melaksanakan tugas dan tanggung jawabnya.

Kemudian faktor pemerintah setempat, kelurahan atau desa yang tidak mempunyai data mengenai tanah-tanah yang sudah disertifikatkan dan sudah ada penguasaannya atau data yang tidak valid. Jika ada orang yang bermohon untuk membuat surat penguasaan tanah yang kemudian diterbitkan, terus tiba-tiba karena ada orang yang niatnya tidak bagus yang datang mengaku memiliki tanah tersebut dan ingin membuat surat penguasaan tanah. Oleh pemerintah setempat dibuatkan dan terkadang mereka tidak melakukan pengukuran, tidak melakukan pengecekan lokasi apakah tanah tersebut benar tanahnya atau tanah tersebut belum terdaftar atas nama orang lain. Atau Untuk wilayah bersangkutan belum tersedia peta pendaftaran tanahnya sehingga lebih memudahkan bagi seseorang yang memiliki niat tidak baik untuk menggandakan sertifikatnya. Selanjutnya adanya surat bukti atau pengaduan hak yang ternyata terbukti mengandung 
ketidakbenaran, kepalsuan, atau tidak berlaku lagi.

Secara formal memang kewenangan Pemerintah untuk mengatur bidang pertanahan tumbuh dan mengakar dari Pasal 33 ayat (3) Undang-Undang Dasar 1945. Kemudian, dituntaskan secara kokoh dalam Undang-Undang Nomor 5 Tahun 1960 tentang Peraturan Dasar Pokok-Pokok Agraria atau UUPA. Seterusnya, menjalar pada berbagai peraturan organik dalam bentuk Peraturan Pemerintah (PP), Keputusan Presiden (keppres), Peraturan Presiden (perpres), serta Peraturan yang diterbitkan oleh pimpinan instansi teknis di bidang pertahanan. ${ }^{12}$

Secara substansial, kewenangan Pemerintah dalam mengatur bidang pertanahan terutama dalam hal lalu lintas hukum dan pemanfaatan tanah, didasarkan pada ketentuan Pasal 2 ayat (2) UUPA yakni dalam halkewenangan untuk mengatur dan menyelenggarakan peruntukan, penggunaan, persediaan dan pemeliharaan tanah termasuk menentukan dan mengatur hubungan-hubungan hukum antara orang-orang dengan tanah dan juga menentukan serta mengatur hubunganhubungan hukum antara orang-orang dengan perbuatan-perbuatan hukum yang mengenai tanah. Dengan ketentuan tersebut, Pemerintah telah diberikan kewenangan yuridis untuk membuat aturan dan peraturan (bestemming) dalam lapangan agrarian berupa tanah, serta menyelenggarakan aturan itu (execution) yang menyangkut subyek, obyek dan hubungan antara subyek dan obyek tersebut sepanjang mengenai sumber daya agraria. ${ }^{13}$

Menurut Mhd. Yamin Lubis dan Abd. Rahim Lubis, tentang pengaturan dalam hal hubungan-hubungan hukum terutama dalam pemberian atau penetapan hak-hak atas tanah jelas telah merupakan kewenangan Negara yang dilaksanakan

12 Dapat dibaca Mhd. Yamin Lubis dan Abd. Rahim Lubis, Hukum Pendaftaran Tanah, Edisi Revisi, Bandung: Mandarmaju, 2010, hal 19

13 Ibid oleh Pemerintah dengan prosedur yang ditentukan dalam peraturan perundangundangan. ${ }^{14}$ Jelaslah bahwa pemberian atau penetapan hak atas tanah hanya dapat dilakukan oleh Negara melalui Pemerintah, sehingga setiap timbul permasalahan maupun persengketaan mengenai hak-hak atas tanah merupakan sebagian dari tugas Pemerintah yang telah diatur dengan undang-undang.

Pemberian atau penetapan hak-hak atas tanah termasuk juga dalam setiap penyelesaian masalah pertanahan dimaksudkan sebagai upaya guna pemberian jaminan kepastian hukum bagi pemegang haknya untuk dapat diberikan jaminan kepastian hukum dan legitimasi dari Negara, maka setiap penguasaan dan pemanfaatan atas tanah perlu didaftarkan sebagaimana diamanatkan dalam Pasal 19 UUPA.

Penulis setuju dengan apa yang telah dikatakan oleh Mhd.Yamin Lubis dan Abd. Rahim Lubis yang menyatakan dalam bukunya Hukum Pendaftaran Tanah terbitan Mandar Maju pada halaman delapan bahwa, "sebenarnya memang bukan tanahnya yang bermasalah, akan tetapi orang yang di atas tanah tersebutlah yang menciptakan masalah tanah, sehingga untuk penanganannya bukan tanahnya yang perlu diamankan, tetapi orangnyalah yang lebih utama diamankan bila di atas tanah mau aman dan bermakna untuk kehidupan manusia di muka bumi ini". ${ }^{15}$

"Sudah menjadi prioritas utama bila kelak Negara ini tidak mau ditimpa masalah pertanahan yang lebih besar, maka disamping melaksanakan peraturan perundangan di bidang pertanahan secara konsekuen juga yang utama ialah upaya pelaksanaan pendaftaran tanah di seluruh Indonesia", demikian lebih lanjut yang dikatakan oleh Mhd. Yamin Lubis dan Abd. Rahim Lubis.

Sudah menjadi program guna

110 Hermeneutika : Jurnal Ilmu Hukum

Vol. 4, No. 2, August 2020

${ }^{14}$ Ibid
${ }^{15}$ Ibid 
meminimalisir kendala pertanahan dengan mengupayakan terus berbagai cara dan strategi dalam pelaksanaan dan percepatan pendaftaran tanah dengan berbagai bentuk kerja lembaga pertanahan seperti prona, program ajudikasi, konsolidasi tanah, redistribusi tanah obyek landreform dan program sertifikasi massal swadaya lainnya. Cara pendaftaran tanah secara sistematik juga menghasilkan peta pendaftaran tanah yang memuat bidangbidang tanah yang sudah didaftar secara terkonsolidasi, sehingga diharapkan dapat dihindari adanya sengketa batas bidang tanah, dan bahwa di atas tanah yang sudah pernah terdaftar pun masih bersengketa atas dasar data teknis yang tidak akurat.

Penegasan yang diatur dalam Peraturan Pemerintah Nomor 24 Tahun 1997 tentang Pendaftaran Tanah, merupakan upaya penyempurnaan terhadap pengaturan yang ada sekaligus penyesuaian terhadap perkembangan kebutuhan masyarakat sebagaimana prinsip yang diamanatkan oleh UUPA. Ketentuan baru pendaftaran tanah dimaksud secara substansial tetap menampung konsep hukum adat yang hidup dan berakar dalam masyarakat, sehingga akan tercapai univikasi hukum yang masih didasarkan pada hukum adat.

Dari paparan di atas, maka penulis melakukan analisis terhadap faktor-faktor yang menyebabkan masih terdapatnya sengketa atas kepastian hukum hak atas tanah yang meski telah bersertifikat hak milik, namun masih menjadi persengketaan oleh warga masyarakat, yang penulis cermati dari adanya putusan Mahkamah Agung Republik Indonesia Nomor 2725 K/PDT/2008 sebagaimana berikut.

1. Faktor Ketentuan Hukum Peraturan Perundang-undangan

Undang-undang memiliki pengertian sebagai ketentuan peraturan yang disusun oleh pemerintah yang disahkan oleh DPR dan unsur-unsur terkait; aturan- aturan yang dibuat oleh penguasa untuk dipatuhi oleh masyarakat; hukum (dalam arti patokan yang bersifat alamiah atau sesuai dengan sifat-sifat alam). ${ }^{16}$

Terhadap penerbitan sertifikat haruslah berpedoman kepada ketentuan Undang-Undang Pokok Agraria, dan undang-undang yang berkaitan dengan prosedur pendaftaran tanah yang berlaku. Menurut Budi Harsono dalam bukunya UndangUndang Pokok Agraria yang dikutip di dalam Putusan MARI No. 2725 K/PDT/2008 bahwa sistem pendaftaran tanah di Indonesia menganut sistem Pendaftaran yang negatif yang bertendensi positif yang maksudnya adalah pihak Pemohon dapat saja mengajukan permohonan untuk mendapat status atas hak suatu tanah di mana pihak Badan Pertanahan haruslah menyampaikan ketentuan yang harus dipenuhi Pemohon dan haruslah diumumkan dan diketahui oleh umum, "dengan kata lain apabila ada pihak-pihak yang dapat membuktikan atas kepemilikan hak terhadap Sertifikat, maka kekuatan Sertifikat tersebut menjadi negatif atau tidak mempunyai kekuatan hukum". Kelemahan sistem publikasi negatif adalah bahwa pihak yang namanya tercantum sebagai pemegang hak dalam buku tanah dan sertifikat selalu menghadapi kemungkinan gugatan dari pihak lain yang merasa mempunyai tanah itu. ${ }^{17}$

Dengan demikian dapat dikatakan bila pihak yang dapat membuktikan kepemilikan hak tanah walau tidak dapat menunjukkan sertifikat, akan tetapi dapat menunjukkan bukti-bukti yang dikuatkan oleh hukum (undang-

\footnotetext{
${ }^{16}$ Tim Prima Pena, Kamus Besar Bahasa Indonesia, Jakarta: Gitamedia Press, 2008, hal 53

17 Budi Harsono, Hukum Agraria Indonesia, himpunan Peraturan-Peraturan Hukum Tanah, Edisi 2008, hal 11
} 
undang), maka hak tanah yang telah mendapatkan sertifikat sekalipun dapat disengketakan. Sehingga faktor undang-undang dapat mempengaruhi dan memungkinkan terjadinya sengketa terhadap tanah yang telah bersertifikat sekalipun.

Dalam hukum adat jika seseorang selama sekian waktu membiarkan tanahnya tidak dikerjakan, kemudian tanah itu dikerjakan oleh orang lain yang memperolehnya dengan iktikad baik, maka hilanglah haknya untuk menuntut kembali tanah tersebut. Untuk itu maka Pemerintah di dalam Pasal 19 UUPA telah menegaskan bahwa untuk memberikan kepastian hukum perlu untuk dilaksanakan pendaftaran atas tanah di seluruh wilayah Indonesia.

Pasal 32 dalam Peraturan Pemerintah Nomor 24 Tahun 1997 dibunyikan bahwa (1) Sertifikat merupakan surat tanda bukti hak yang berlaku sebagai alat pembuktian yang kuat mengenai data fisik dan data yuridis yang termuat di dalamnya, sepanjang data fisik dan data yuridis tersebut sesuai dengan data yang ada dalam surat ukur dan buku tanah hak yang bersangkutan. (2) Dalam hal atas suatu bidang tanah sudah diterbitkan sertipikat secara sah atas nama orang atau badan hukum yang memperoleh tanah tersebut dengan iktikad baik dan secara nyata menguasainya, maka pihak lain yang merasa mempunyai hak atas tanah itu tidak dapat lagi menuntut pelaksanaan hak tersebut apabila dalam waktu 5 (lima) tahun sejak diterbitkannya sertipikat itu tidak mengajukan keberatan secara tertulis kepada pemegang sertipikat dan Kepala Kantor Pertanahan yang bersangkutan ataupun tidak mengajukan gugatan ke Pengadilan mengenai penguasaan tanah atau penerbitan sertipikat tersebut.

$$
\text { Ketentuan undang-undang }
$$

menyebutkan apabila ada pihak-pihak yang dapat membuktikan atas kepemilikan hak terhadap sertifikat, maka kekuatan sertifikat tersebut menjadi negatif atau tidak mempunyai kekuatan hukum. Kasus-kasus pengadilan yang menyangkut sengeketa tanah sering merupakan pertarungan kekuasaan sekaligus pertarungan hukum (undang-undang) ${ }^{18}$ sengatlah penting agar dapat diketahui umum di pengadilan, karena kemudian dapat dilaporkan (walaupun dengan samar-samar) oleh media cetak secara jauh lebih rinci. Sebuah kasus pengadilan dapat juga memberikan dampak nasional terhadap sengketasengketa lokal. Kasus-kasus pengadilan bisa pula digunakan sebagai forum untuk mempublikasikan pelanggaran-pelanggaran hak atas tanah, yang menurut banyak organisasi non-pemerintah merupakan aspek sengketa tanah yang sering tidak dibicarakan.

Konflik atau sengketa tanah pada masa Orde Baru dulu banyak terjadi antara rakyat dengan pemilik modal, atau antara rakyat dengan Negara, atau antara rakyat dengan pemilik modal yang beraliansi dengan Negara. Dengan kata lain, konflik atau sengketa tanah pada massa Orde Baru merupakan konflik antara rakyat di satu pihak dengan Negara dan pemodal di pihak lain yang merupakan wujud dari proses akumulasi primitif yang terkait dengan ketidakadaannya kepastian hukum dikarenakan minim perundang-undangan.

2. Faktor Sumber Daya Manusia

Menurut Lawrence M. Friedman, Hukum bukan sekedar alat yang dapat dimanfaatkan untuk tujuan tertentu,

18 Pratikno, Repression and Resistence: Statepromotted Development and the Disenfranchised Urban Poor in Indonesia, 1995, hal 20 
tetapi juga merupakan perangkat tradisi, obyek pertukaran nilai yang tidak netral dari pengaruh sosial dan budaya. ${ }^{19}$ Budaya dapat berfungsi sebagai kerangka normatif dalam kehidupan manusia untuk menentukan perilaku, sehingga budaya dapat dikatakan sebagai sitem perilaku.

$\begin{gathered}\text { Budaya hukum rangat } \\ \text { mempengaruhi } \\ \text { efektifitas }\end{gathered}$
berperilaku dan keberhasilan dalam
penegakan hukum. Hukum
merupakan konkretisasi nilai-nilai
sosial yang terbentuk dari
kebudayaan. Kegagalan hukum
modern seringkali karena tidak
compatible dengan budaya hukum
masyarakat. Ada dua kelompok
budaya hukum: ${ }^{20}$
a. Budaya Hukum Prosedural
yaitu nilai-nilai yang ada dalam
masyarakat dalam
menyelesaikan sengketa dan
dalam manajemen konflik.

b. Budaya Hukum Substantif yaitu asumsi-asumsi fundamental terutama mengenai apa yang adil dan tidak menurut kelompok manusia atau masyarakat.

Manusia merupakan makhluk ciptaan Tuhan yang memiliki akal dan pikiran. Dengan akal dan pikiran, manusia dapat berbuat atau melakukan sesuatu sesuai yang dia inginkan. Tidak sedikit manusia yang memiliki sifat keinginan yang lebih dari pada apa yang dia punya. Karena inilah mengapa terjadinya sengketa tanah yang disebabkan oleh manusia itu sendiri.

Dengan terbitnya Peraturan Pemerintah Nomor 24 Tahun 1997

${ }^{19}$ Lawrence M. Friedman, The Legal System, New York: Russel Sage Foundation, 1975

${ }^{20}$ Daniel S. Lev, Hukum dan Politik di Indonesia, Bandung: Nusa Media, 1990, hal 66 tentang Pendaftaran Tanah, pendaftaran tanah dilaksanakan untuk memberikan jaminan akan kepastian hukum dalam bidang pertanahan dan bahwa sistem pendaftarannya adalah sistem publikasi negatif yang bertendensi positif, karena akan menghasilkan surat- surat bukti hak yang berlaku sebagai salah satu alat pembuktian yang kuat. Dalam sistem negatef bahwa sertifikat tersebut hanya dapat dipandang sebagai suatu bukti permulaan hak atas tanahnya, atau sertifikat sebagai salah satu alat pembuktian yang kuat sehingga setiap orang dapat mempersoalkannya kembali.

Lalu dengan mengandung unsur positif, ditujukan untuk memberikan kepastian hukum kepada pihak yang dengan iktikad baik menguasai sebidang tanah dan didaftar sebagai pemegang hak dalam buku tanah dan dengan diterbitkannya sertifikat sebagai sala satu alat bukti yang kuat.

\section{Faktor Teknis}

Dalam pendaftaran tanah dapat meliputi pengukuran, pemetaan dan pembukuan tanah; pendaftaran hakhak atas tanah dan peralihan hakhak tersebut; serta pemberian surat tanda bukti hak. Kegiatan pengukuran dan pemetaan kadastral merupakan rangkaian kegiatan teknis yang tidak dapat dipisahkan. Kegiatan pengukuran merupakan kegiatan pengambilan data fisik di lapangan yang meliputi data letak, batas, bentuk dan luas atas bidangbidang tanah yang kemudian diikuti dengan kegiatan pemetaan kedalam Peta Dasar Pendaftaran atau Peta Pendaftaran.

Untuk memberikan jaminan kepastian hukum mengenai letak , 
batas dan luas terhadap bidang tanah yang didaftar, hasil dari kegiatan pengukuran harusnya dipetakan ke dalam satu Peta Pendaftaran. Namun masih ada juga yang memetakan dengan beberapa peta dasar pendaftaran. Oleh karenanya, timbul keraguan atas letak tanah tersebut dan dapat menimbulkan sengketa hak atas tanah yang telah bersertifikat.

Putusan majelis hakim pada perkara nomor 103/G/2016/PTUN-BDG sudah tepat karena Para Penggugat merasa kepentingannya dirugikan akibat diterbitkannya objek sengketa berupa sertipikat hak milik atas tanah di atas tanah milik para Penggugat yang secara admistratif sudah terdaftar di kantor Pertanahan Kota Bandung Dan Kepala Kantor Pertanahan Kota Bandung yang kapasitasnya dalam sengketa ini selaku Pejabat Tata Usaha Negara yang menerbitkan objek sengketa berupa SERTIPIKAT HAK MILIK NO.4298/ANCOL TERBIT TANGGAL 04 SEPTEMBER 2015, SURAT UKUR NO.00077/ANCOL/2015 TANGGAL 29 JUNI 2015, SELUAS $3.550 \mathrm{M}^{2}$ (TIGA RIBU LIMA RATUS LIMA PULUH METER PERSEGI), ATAS NAMA USWATUN HASANAH, yang merupakan yang disengketakan. yang menjadi pokok permasalahan. Menurut penulis juga, gugatan para tergugat sudah tepat diajukan ke pengadilan Tata Usaha Negara, karena sengketa ini merupakan sengketa Tata Usaha Negara yang mana memasuki ranah sengketa administrasi dimana untuk menguji sengketa ini berdasarkan ketentuan pasal 1 angka 10 Undang-Undang Nomor 51 Tahun 2009 tentang Perubahan kedua atas UndangUndang Nomor 5 Tahun 1986 tentang Peradilan Tata Usaha Negara, merupakan kewenangan absolut mengadili dari Peradilan Tata Usaha Negara.

Telah terjadi tumpang tindih sertipikat (overlap) pada sebagian SERTIFIKAT HAK MILIK
NO.1490/ANCOL, TERBIT TANGGAL 5 FEBRUARI 1986, GAMBAR SITUASI NO.4201/1985 TANGGA 5 FEBRUARI 1986, SELUAS 6.580 M2 (ENAM RIBU LIMA RATUS DELAPAN PULUH METER PERSEGI), ATAS NAMA HAJJAH SUTIAH,cs (PARA PENGGUGAT), terletak di Propinsi Jawa Barat, Kotamadya Daerah Tk II Bandung Wilayah Karees, Kecamatan Regol, Kelurahan Ancol.

Berdasarkan permasalahan tersebut di atas yang harus diuji adalah apakah penerbitan objek sengketa di atas tanah yang telah bersertipikat telah sesuai dengan Peraturan perundang- undangan yang berlaku dan asas-asas umum pemerintahan yang baik ataukah sebaliknya. Pada pasal 3 Peraturan Pemerintah No. 24 tahun 1997 tentang Pendaftaran Tanah Pendaftaran tanah bertujuan: "a. untuk memberikan kepastian hukum dan perlindungan hukum kepada pemegang hak atas suatu bidang tanah, satuan rumah susun dan hak-hak lain yang terdaftar agar dengan mudah dapat membuktikan dirinya sebagai pemegang hak yang bersangkutan". Bedasarkan ketentuan tersebut maka dapat penulis simpulkan bahwa suatu bidang tanah yang didaftarkan bertujuan untuk memberikan kepastian hukum dan perlindungan hukum kepada pemegang hak atas suatu bidang tanah. Karena Tanah yang telah diterbitkan objek sengketa sebelumnya telah diterbitkan terlebih dahulu sertipikat hak milik No.1490/ANCOL, dahulu atas nama Ny. Warka Sastradinata,yang kemudian beralih Dra.SALAMAH ADIPURA karena jual beli berdasarkan Akta jual beli tanggal 19-71986 No. 227/7/1986 dan sekarang telah beralih haknya kepada Para Ahli Warisnya yaitu Hj. SUTIAH Cs (PARA PENGGUGAT) seluas 6.580M2 Dan Terdapat Fakta Bahwa tercatat atas nama Para Penggugat, dan berdasarkan data fisiknya belum terdapat pemecahan atau pemisahan.

Tergugat dalam menerbitkan sertipikat objek sengketa tidak mendasarkan 
pada Peraturan perundang-undangan yang berlaku karena Tergugat tidak meneliti dan mencocokan data yang ada pada daftar buku tanah Sertipikat Hak Milik nomor 1490/Ancol milik Para Penggugat yang terdapat di Kantor Pertanahan Kota Bandung namun Tergugat tetap memproses permohonan sertipikat yang diajukan oleh Uswatun Hasanah, seharusnya apabila Tergugat meneliti dan mencocokan data pada daftar buku tanah Sertipikat Hak Milik No. 1490/Ancol milik Para Penggugat yang tersimpan diKantor Pertanahan Kota Bandung terlebih dahulu, maka dapat dihindari terjadinya tumpang tindih bidang tanah objek sengketa dengan Sertipikat Hak Milik No. 1490/Ancol milik Para Penggugat.

Berdasarkan ketentuan tersebut di atas penerbitan objek sengketa di atas tanah yang telah didaftarkan tanah hak milik Para Penggugat di kantor pertanahan Kota Bandung menurut Penulis tindakan Tergugat tersebut telah bertentangan dengan PP No. 24 tahun 1997 karena tidak sesuai lagi dengan pasal 3 yang memberikan kepastian hukum bagi pemegang hak dan penerbitan objek sengketa mengandung cacat administrasi karena terjadi tumpang tindih serta bertentangan dengan asas kecermatan karena tidak meneliti dengan cermat terhadap data yang seharusnya diketahui oleh Tergugat bahwa tanah tersebut telah terdaftar di Kantor Pertanahan Kota Bandung.

\section{KESIMPULAN}

Setelah melakukan penelitian dan analisis terhadap pembatalan sertipikat hak atas tanah sebagai penyelesaian sengketa kepemilikan ganda atas tanah, maka dapat dikemukakan kesimpulan-kesimpulan sebagai berikut:

1. Peran Agraria (ATR-BPN) Dalam Menanggulangi Sertifikat Ganda sehingga menjadi penyebab terjadinya pemilikan ganda dalam Perkara nomor 103/G/2016/PTUN-BDG: a. Tidak dilakukan pengukuran tanah, yang merupakan suatu keharusan dalam kegiatan pendaftaran tanah seperti yang disyaratkan dalam Pasal 19 Undang-Undang Nomor 5 Tahun 1960 tentang Peraturan Dasar Pokok-pokok Agraria. Kesalahan Badan Pertanahan Nasional melalui para petugas yang tidak mengetahui keadaan, status tanah, dan batas-batas bidang tanah. Pada saat pengukuran bidang tanah dilakukan pun tidak dilakukan pengukuran secara teliti.

b. Dalam pelaksanaan pengukuran tanah hanya memperhatikan permohonan obyek tanah yang dimaksud, tanpa memperhatikan batasan-batasan dari tanah yang berada berdampingan dengan tanah obyek pengukuran.

2. Putusan Hakim dalam Perkara Nomor 103/G/2016/PTUN-BDG yang membatalkan surat keputusan Tata Usaha Negara yang diterbitkan Kantor Pertanahan Bandung berupa SERTIPIKAT HAK MILIK NO.4298/ANCOL berdasarkan ketentuan dalam Pasal 19 UUPA dan Peraturan Pemerintah Nomor 24 Tahun 1997 tentang Pendaftaran telah memberikan persyaratan dalam melakukan kegiatan pendaftaran tahan yang dapat mencegah terjadinya kepemilikan ganda atas tanah adalah sebagai berikut:

a. Pengukuran bidang tanah pada saat pendaftaran tanah dengan mengikuti aturan mengenai tata cara pengukuran yang diatur dalam Pasal 14 sampai dengan Pasal 22 Peraturan Pemerintah Nomor 24 Tahun 1997 tentang Pendaftaran Tanah dan pembukuannya yang telah diatur dalam Pasal 29 dan 30 Peraturan Pemerintah Nomor 24 Tahun 1997 tentang Pendaftaran tanah.

b. Memperhatikan batasan bidangbidang tanah dan pelaksanaan asas delimitatie contradictoire sesuai pasal 17 ayat (2) Peraturan Pemerintah Nomor 24 Tahun 1997 tentang Pendaftaran Tanah yang dilaksanakan dengan cermat, dengan menelusuri kebenaran data yang 
disampaikan dari pihak-pihak yang letak bidang tanahnya berbatasan.

c. Dari segi tata usaha negaranya sendiri para pejabat dari Kantor Pertanahan harus melakukan tugasnya secara cermat dan teliti, berpedoman kepada peraturan perundang-undangan yang berlaku, peraturan jabatan, etika profesi, serta norma-norma yang berlaku di masyarakat. Melakukan tugas dan tanggung jawab mereka dengan baik, dan tidak melakukan pelanggaran hukum.

\section{DAFTAR PUSTAKA}

A. Buku

Abdurrahman, Kedudukan Hukum Adat dalam Perundang-Undangan Agraria, Jakarta: Akademika Presindo, 2003

Ali Achmad Chomzah, Hukum Agraria (Pertanahan) Indonesia, Jilid 2, Jakarta: Prestasi Pustaka Publiser, 2004

Arie S. Hutagalung (B), Tebaran Pemikiran Seputar Masalah Hukum Tanah), (Jakarta: Lembaga Pemberdayaan Hukum Indonesia, 2015

Boedi Harsono, Menuju Penyempurnaan Hukum Tanah Nasional, Jakarta: Universitas Trisakti, 2002

Daniel S. Lev, Hukum dan Politik di Indonesia, Bandung: Nusa Media, 1990

Eko Budi Wahyono, Alternatif Pemanfaatan Citra Satelit IKONOS Untuk Peta Pendaftaran Sistem Tunggal, Makalah Untuk Forum Ilmiah Tahunan Ikatan Surveyor Indonesia, (tidak dipublikasikan), Yogyakarta, 2005

Hadjon, Philipusd M., Akta PPAT Bukan Keputusan Tata Usaha Negara, Surabaya : 1 Juli 1996

Imam sudiyat, Hukum Adat Sketsa Asas, Cet ke IV, Yogyakarta: Liberty, 2018

Irawan Soerodjo, Kepastian Hukum Hak Atas Tanah di Indonesia, Surabaya: Arloka, 2003

J.C.T. Simorangkir \& Woerjono Sasropranoto, Pelajaran Hukum
Indonesia, Jakarta: Gunung Agung, Cet ke vii, 2019

Lawrence M. Friedman, Sistem Hukum Perspektif Ilmu Sosial, Bandung: Nusa Media, 2009

Muchsin, Hukum Agraria Indonesia Dalam Perspektif Sejarah, Bandung Refika Aditama, 2007

Mhd. Yamin Lubis dan Abd. Rahim Lubis, Hukum Pendaftaran Tanah, Edisi Revisi, Bandung: Mandarmaju, 2010

P. Parlindungan, Komentar UndangUndang Pokok Agraria, Bandung, 2013: Mandar Maju

Soelaman, Br, Pelaksanaan Pendaftaran Tanah Menurut Peraturan Pemerintah Nomor 24 Tahun 1997, Jakarta : 1997

Sumardjono, Maria, Kebijakan Pertanahan Antara Regulasi dan Implementasi, Jakarta : Kompas, 2006

Sutedi, Adrian, Peralihan Hak Atas Tanah, Cet. 1, Jakarta : Sinar Grafika, 2007

Yulia Mirwati, ,Konflik-konflik Mengenai Tanah Ulayat Dalam Era Reformasi di Daerah Sumatra Barat, Disertasi, Universitas Sumatera Utara, Medan, 2000

Tim Prima Pena, Kamus Besar Bahasa Indonesia, Jakarta: Gitamedia Press, 2008

Pratikno, Repression and Resistence: Statepromotted Development and the Disenfranchised Urban Poor in Indonesia, 1995

B. Undang-Undang

UU Nomor 5 Tahun Tentang Pokok-Pokok Agraria

PP Nomor 24 Tahun 1997 Tentang Pendaftaran Tanah

\section{Lain-Lain}

Khairina, "Kalau bisa Dipersulit, Kenapa Dipermudah?" Kompas (30 Juni 2017)

http://fauzie6961.blog.esaunggul.ac.id, pendaftaran tanah,4/6/2012, diunduh pukul $21.15 \mathrm{wib}$

Putusan Nomor. 103/G/2016/PTUN-BDG 